\title{
PENGEMBANGAN INSTRUMEN PENILAIAN SIKAP \\ DISPOSISI MATEMATIS PADA MATERI FPB DAN KPK \\ SD/MI TUNANETRA
}

Ahmad Surohman

Universitas Islam Negeri Sunan Kalijaga, Yogyakarta, Indonesia

Email: 0nesmile.mama@gmail.com

\begin{abstract}
ABSTRAK
Penelitian ini memiliki tujuan untuk mengembangkan dan menilai kelayakan produk instrumen penilaian disposisi matematis pada materi Faktor Persekutuan Terbesar dan Kelipatan Persekutuan Terkecil di Sekolah Dasar Luar Biasa untuk tunanetra. Penelitian ini dilakukan dengan penelitian dan pengembangan model 4D yang meliputi 4 tahap: Define, Design, Development dan Dissemination Penelitian ini berhasil mengembangkan instrumen penilaian disposisi matematis pada materi FPB dan KPK untuk siswa tunanetra di Sekolah Dasar Luar Biasa dengan kelayakan produk ditunjukkan dengan koefisien reliabel pada uji coba ketiga sudah memenuhi 0,7 sehingga error datanya sebesar $30 \%$. Di samping itu melalui uji para ahli, produk ini juga mendapatkan penilaian layak.
\end{abstract}

\section{Kata Kunci: Disposisi Matematis, FPB, Instrumen Penilaian, Tunanetra, KPK.}

\section{ABSTRACT}

This research aims to develop and assess the feasibility of the product of a mathematical disposition assessment instrument in the material of the Biggest Guild Factor (BGF) and the Smallest Multiple Multiplication (SMM) in the Extraordinary Primary School for the blind. This research was conducted with research and development of the 4D model which includes 4 stages: Define, Design, Development and Dissemination This study succeeded in developing mathematical disposition assessment instruments for $B G F$ and SMM material for blind students in Extraordinary Primary Schools with product feasibility indicated by reliable coefficients in the third trial it has fulfilled 0.7 so that the data 
error is $30 \%$. In addition, through expert testing, this product also received a decent assessment.

\section{Keywords: Mathematical Disposition, Biggest Guild Factor,} Assessment Instruments, Blind, Smallest Multiple Multiplication

\section{A. PENDAHULUAN}

Undang-undang Republik Indonesia tahun 1945 pasal 31 tentang pendidikan dan kebudayaan telah menyatakan bahwa setiap warga Negara berhak mendapatkan pendidikan ${ }^{1}$ baik anak normal ataupun berkebutuhan khusus seperti tunanetra, karena setiap anak memiliki potensi yang berbeda-beda sehingga pendidikan diharapkan dapat dinikmati oleh setiap warga negara. Tujuan pendidikan nasional adalah mengembangkan potensi peserta didik agar menjadi manusia yang beriman dan bertakwa terhadap Tuhan Yang Maha Esa, berakhlak mulia, sehat, berilmu, cakap kreatif, mandiri dan menjadi warga negara yang demokratis serta bertanggug jawab. ${ }^{2}$ Bagi peserta didik penyandang disabilitas seharusnya dapat mengembangkan potensinya sehingga dapat memenuhi tujuan pendidikan nasional tersebut.

Potensi yang dimiliki anak dapat dikembangkan menjadi keahlian yang handal manakala selalu dievaluasi dan dikembangkan. Evaluasi tidak terlepas dari proses penilaian, begitu juga penilaian terhadap anak-anak yang berkebutuhan khusus termasuk anak tunanetra. Penilaian ini dilakukan untuk mengukur dan menilai tingkat pencapaian kurikulum dan

\footnotetext{
1 Presiden Republik Indonesia, Undang-Undang Dasar Negara Republik Indonesia Pasal 31 Tahun 1945.

2 Presiden Republik Indonesia, Undang-Undang No 20 Tahun 2003 Tentang Sistem Pendidikan Nasional.
} 
keberhasilan proses pembelajaran. ${ }^{3}$ Penilaian juga dapat digunakan untuk mengetahui kelemahan dan kelebihan proses pembelajaran sehingga dapat digunakan sebagai pedoman untuk memperbaiki kinerja tenaga kependidikan, ${ }^{4}$ Terlebih pendidikan Indonesia yang masih memiliki berbagai masalah pendidikan. Seperti yang dimuat dalam laman $d$ w.com yang mengemukakan bahwa pendidikan Indonesia masih tertinggal di antara negera-negara ASEAN, bahkan dibandingkan negara yang lebih miskin, Indonesia hanya menempati peringkat ke 5 di bawah Thailand, Malaysia, Brunei Darussalam dan Singapura. ${ }^{5}$

Even tiga tahunan dengan nama Programme for International Student Assessment (PISA) yang diadakan di Paris, Prancis tahun 2015, Indonesia hanya mampu menempati posisi 63 dari 65 peserta di bidang Matematika, masih tertinggal dari beberapa negara tetangga seperti Thailand yang menempati peringkat 55, Vietnam yang menempati peringkat 8 dan Singapura yang menempati peringkat $1 .^{6}$ Hasil ini menandakan bahwa tingkat pemahaman matematika di Indonesia masih lemah.

Survei dari transparansi internasional yang menyusun peringkat korupsi di 180 negara, Indonesia menempati urutan 96 bersama Brazil, Kolombia, Panama, Peru, Thailand dan Zambia, masih di bawah negara-negara ASEAN seperti Singapura yang menempati urutan ke 6, Brunei Darussalam menempati urutan ke

\footnotetext{
${ }^{3}$ Sudaryono, Dasar-Dasar Evaluasi Pembelajaran (Yogyakarta: Graha Ilmu, 2012), hlm. 72.

${ }_{5}^{4}$ Sudaryono.

5 Admin Sosbud, Rangking Pendidikan Negara-negara Asean, 2018, http://www.dw.com/id/rangking-pendidikan-negara-negara-asean/g-37594464.

6 Angel Gurria, PISA Result in Focus, 2018, https://www.oecd.org/pisa/pisa2015-results-in-focus.pdf.
} 
32, Malaysia menempati urutan ke 62 dan Timor Leste menempati urutan ke $91 .{ }^{7}$ Survei ini menunjukkan bahwa tingkat sikap moral di Indonesia masih rendah sebagai mana yang dikemukakan oleh Kostogiannis Dreher dan Mc Corriston.

Kostogiannis Dreher dan Mc Corriston mengidentifikasikan empat faktor yang mejadi penyebab munculnya korupsi, yaitu; 1) faktor politisi dan yudisial, 2) faktor historis, 3) faktor sosial dan budaya, 4) faktor ekonomi. Faktor sosial dan budaya pada hakikatnya tekait dengan sikap moral. Orang yang memiliki sikap moral yang terpuji cenderung menjauhkan diri dari perbuatan-perbuatan korupsi. Mereka cenderung membuat keputusan dan mengimplementasikan program dalam berbagai kegiatan yang cenderung menghindarkan dirinya dari perbuatan yang merugikan orang lain atau pihak lain. ${ }^{8}$ Rendahnya pemahaman sikap moral ini salah satunya dipengaruhi oleh rendahnya penilaian, khususnya pada fokus matematika.

Untuk mempermudah proses penilaian maka dibutuhkan alat ukur yang dinamakan alat penilaian (alat evaluasi) atau dikenal juga dengan instrumen evaluasi. Instrumen evaluasi ini dikatakan baik apabila dapat mengevaluasi dengan hasil yang sesuai dengan keadaan yang dievaluasi. ${ }^{9}$ Penyusunan instrumen penilaian sangat penting dalam proses penilaian. Sebab, tepat tidaknya data yang

\footnotetext{
${ }^{7}$ Ervan Hardoko, Indeks Persepsi 2017: Peringkat Indonesia di Bawah Timor Leste, 2017 , https://internasional.kompas.com/read/2018/02/26/14444501/indeks-persepsikorupsi-2017-peringkat-indonesia-di-bawah-timor-leste.

8 Junaidi I Ketut Patra, "Korupsi, Pertumbuhan Ekonomi Dan Kemiskinan Di Indonesia," Riset Akuntansi Dan Keuangan Indonesia 3, no. 1 (2018): 71-79, https://doi.org/10.23917/reaksi.v3i1.5609.

${ }^{9}$ Suharsimi Arikunto, Dasar-Dasar Evaluasi Pendidikan, Revisi (Jakarta: Bumi Aksara, 2010), hlm. 26.
} 
diperoleh sangat tergantung dengan baik tidaknya instrumen penilaian yang digunakan. ${ }^{10}$

Berdasarkan hasil wawancara dengan Sri Wahyuni Endaryati selaku guru matematika di SLB A Yaketunis Yogyakarta mengatakan bahwa instrumen penilaian baku yang diperuntukkan bagi penyandang tunanetra tidak tersedia, ${ }^{11}$ begitu juga yang di kemukakan oleh Abdul Adim ${ }^{12}$ dan Amirudin AlQodri ${ }^{13}$. Jadi guru sendirilah yang membuat instrumen penilaian tersebut. Amiruddin Al-Qodri selaku guru kelas SLB N 1 Kulon Progo, beliau menambahkan bahwa setiap peserta didik dianggap memiliki kemampuan yang berbeda, sehingga satu peserta didik membutuhkan satu RPI (Rencana Pembelajaran Individu) dan membutuhkan instrumen penilaian yang berbeda baik mata pelajaran Matematika, IPA Bahasa Indonesia maupun Ilmu Pengetahuan Sosial, dalam hal ini pemerintah hanya menyediakan kompetensinya selebihnya guru yang lebih berperan. ${ }^{14}$

Sri Wahyuni Endaryati menuturkan bahwa instrumen yang dibuat tidak sempat untuk diuji secara detail, hanya pada even tertentu saja seperti ujian nasional. Jadi pengembangan instrumen

\footnotetext{
10 Wayan Nurkancana and Sunartana, Evaluasi Pendidikan (Surabaya: Usaha Nasional, 1986), hlm. 9.

11 Wawancara dengan Ibu Sri Wahyuni Endaryati, guru matematika SLB A Yaketunis Yogyakarta, di ruang tamu SLB A Yaketunis Yogyakarta, tanggal 16 Januari 2018.

12 Wawancara dengan Bapak Abdul Abidin, guru kelas 4 SLB N 1 Bantul Yogyakarta, di ruang media SLB N1 Bantul Yogyakarta, tanggal 01 Februari 2018 di SD SLB N 1 Bantul Yogyakarta

${ }^{13}$ Wawancara dengan Bapak Amiruddin Al Qodri, guru kelas 4 dan 5 SLB N 1 Kulon Progo, di ruang kelas 4 dan 5 SLB N 1 Kulon Progo Yogyakarta, tangal 02 Februari 2018.

${ }^{14}$ Wawancara dengan Bapak Amiruddin Al Qodri, guru kelas 4 dan 5 SLB N 1 Kulon Progo, di ruang kelas 4 dan 5 SLB N 1 Kulon Progo Yogyakarta, tangal 02 Februari 2018.
} 
penilaian ini dibutuhkan, guna membantu proses penilaian di sana. Berdasarkan wawancara dari salah satu siswa (Refli) pemberian evaluasi hanya berupa soal-soal saja. Hal ini tentu saja kurang memberikan hasil yang memuaskan khususnya dalam sikap peserta didik. ${ }^{15}$ Ratna dan Sofia selaku guru kelas 4 dan 3 menuturkan bahwa nilai berhitung peserta didik kelas 4 masih kurang. Disebabkan hanya 1 peserta didik yang dapat memenuhi KKM yang telah disediakan. Dua peserta didik lainnya mengalami kesulitan dalam mencapai KKM. ${ }^{16}$ Hal ini menunjukkan kemampuan matematika peserta didik masih kurang.

Kemampuan matematika yang baik memiliki lima komponen yang saling berhubungan yaitu; memiliki sikap disposisi matematis yang bersamaan dengan kompetisi strategis, penalaran adaptif, kelancaran prosedural dan pemahaman konseptual. ${ }^{17}$ Sehingga dapat disimpulkan jika kemampuan kompetisi strategis, penalaran adaptif, kelancaran prosedural dan pemahaman konseptual bagus, tanpa adanya disposisi matematis yang baik, maka kemampuan matematika peserta didik akan kurang.

\footnotetext{
15 Wawancara dengan Refli, siswa kelas 4 SLB A Yaketunis Yogyakarta. Di depan ruang kelas 4, tanggal 16 Januari 2018.

${ }^{16}$ Wawancara dengan Ibu Ratna Dyah Astuti, Wali Kelas 4 SLB A Yaketunis Yogyakarta, di Ruang Tamu SLB A Yaketunis Yogyakarta, dan dengan Ibu Sofia Patriati H, Wali Kelas 3, di Ruang Kelas 3 SLB A Yaketunis Yogyakarta, tanggal 21 November 2018.

17 C. Adam Feldaus, "How Mathematical Disposition and Intellectual Development Influence Teacher Candidates' Mathematical Knowledge for Teaching in a Mathematics Course for Elementary School Teachers" (Disertasi, Ohio: The Patton College of Education, 2012), hlm. 43, https://etd.ohiolink.edu/!etd.send_file?accession=ohiou1343753975\&disposition $=$ inline.
} 
Hal ini selaras dengan penelitian yang dilakukan oleh Maula Amalia Maghfuroh yang melakukan penelitian dengan judul "Pengaruh Kecerdasan Emosional dan Disposisi Matematis Peserta Didik Terhadap Hasil Belajar Kognitif Matematika di Kelas XI MA NU 10 Sukorejo" yang menyatakan bahwa pengaruh disposisi matematis terhadap hasil belajar peserta didik sebesar 31,94\%. ${ }^{18}$ Hal ini menunjukkan pentingnya disposisi matematis yang baik dalam pembelajaran matematika.

SD Yaketunis sebagai penyelenggara pendidikan tunanetra di Kota Yogyakarta, memiliki peserta didik kelas empat tiga orang. Di mana satu orang mengalami ketunaan total sedangkan dua orang mengalami low vision, sehingga pengembangan instrumen ini dikhususkan di SD Yaketunis Yogyakarta. Dari fenomenafenomena yang muncul, peneliti berusaha untuk mengembangkan instrumen penilaian sikap untuk peserta didik yang berkebutuhan khusus yaitu tunanetra pada mata pelajaran Matematika.

\section{B. METODE PENELITIAN}

Penelitian ini merupakan penelitian Reseach and Development (R\&D). Penelitian pengembangan ini menggunakan metode 4D yang memiliki empat tahap yaitu: Define, Design, Development dan Dissemination. ${ }^{19}$ Define memiliki dua kegiatan yaitu: ${ }^{20}$ Pertama, mengidentifikasi masalah (Identify Problem), pada tahap ini peneliti melakukan observasi di SDLB yaitu SDLB

\footnotetext{
18 Maula Amalia Maghfuroh, "Pengaruh Kecerdasan Emosional Dan Disposisi Matematis Peserta Didik Terhadap Hasil Belajar Kognitif Matematika Di Kelas XI MA NU 10 Sukorejo" (Skripsi, Universitas Islam Negeri Walisongo Semarang, 2016), http://eprints.walisongo.ac.id/5898/8/LAMPIRAN.pdf.

19 Endang Mulyatiningsih, Metode Penelitian Terapan Bidang Pendidikan, 1st ed. (Bandung: Alfabeta, 2012), hlm. 195.

${ }^{20}$ Mulyatiningsih, hlm. 196.
} 
A Yaketunis Yogyakarta, dan peneliti menemukan bahwa belum tersedianya instrumen penilaian sikap yang digunakan dalam penilaian proses evaluasi dan hanya berupa soal-soal kognitif saja. ${ }^{21}$ Selain itu peneliti juga melakukan wawancara kepada guru kelas 4 yaitu Ratna dan guru kelas 3 terdahulu yaitu Sofia bahwa nilai berhitung peserta didik kelas 4 masih kurang. Disebabkan hanya 1 peserta didik yang dapat memenuhi KKM yang telah disediakan. Dua peserta didik lainnya mengalami kesulitan dalam mencapai KKM. ${ }^{22}$ Kedua, Menganalisis latar (analize setting) dilakukan dengan mengumpulkan data tentang karakteristik sasaran, yakni sasaran dalam penelitian ini adalah peserta didik tunanetra sebagai subjek penelitian, kondisi di mana kegiatan akan berlangsung dalam penelitian ini adalah di SDLA A Yaketunis Yogyakarta. Hambatan yang ada dalam penelitian ini adalah keterbatasan subjek penelitian yang mana relatif sedikit dan biaya pengembangan yang cukup mahal.

Design memiliki berapa kegiatan yaitu: ${ }^{23}$ Pertama, munculnya potensi dan masalah yaitu, belum adanya instrumen penilaian sikap yang digunakan dalam penilaian proses evaluasi dan hanya berupa soal-soal saja ${ }^{24}$ dan masih kurangnya kemampuan berhitung peserta

\footnotetext{
21 Wawancara dengan Refli, siswa kelas 4 SLB A Yaketunis Yogyakarta, di depan ruang kelas 4, tanggal 16 Januari 2018.

${ }^{22}$ Wawancara dengan Ibu Ratna Dyah Astuti, Wali Kelas 4 SLB A Yaketunis Yogyakarta, di Ruang Tamu SLB A Yaketunis Yogyakarta, dan dengan Ibu Sofia Patriati H, Wali Kelas 3, di Ruang Kelas 3 SLB A Yaketunis Yogyakarta, tanggal 21 November 2018.

${ }^{23}$ Sugiyono, Metode Penelitian Dan Pengembangan (Bandung: Alfabeta, 2017), hlm. 446.

${ }^{24}$ Wawancara dengan Refli, siswa kelas 4 SLB A Yaketunis Yogyakarta, di depan ruang kelas 4, tanggal 16 Januari 2018.
} 
didik kelas $4 .{ }^{25}$ Kedua, tujuan produk ini adalah tersedianya produk alat untuk mengukur sikap disposisi matematis materi FPB dan KPK. Ketiga, pengembangan ide, pengembangan ide ini dilakukan atas dasar masukan dari dosen pembimbing sehingga dipilihlah pengembangan instrumen sikap disposisi matematis. Pada tahap ini produk baru berupa rancangan dalam proposal. Keempat, penyaringan ide, dalam tahap ini peneliti melakukan penyaringan atas masukan dari dosen pembimbing. Kelima pengevaluasian, pada tahap ini peneliti meminta masukan dari dosen pembimbing dalam pembuatan instrumen yang akan digunakan sebagai sebuah produk instrumen penilaian sikap disposisi matematis. Pada tahap ini produk belum dibuat dan masih berupa proposal. Keenam pertimbangan konsumen, dalam tahap ini peneliti meminta pendapat dari guru matematika SDLB A Yaketunis bahwa instrumen penilaian sikap disposisi matematis ini perlu atau layak dikembangkan. ${ }^{26}$ Ketujuh, desain produk kasar atau permulaan.

Develop memiliki dua kegiatan yaitu: ${ }^{27}$ Pertama expert appraisal, merupakan teknik untuk memvalidasi atau menilai kelayakan rancangan produk yang dilakukan oleh para ahli yang ahli dalam bidangnya. Para ahli tersebut, adalah Ahli Evaluasi yang diwakili oleh Runtut Prih Utami, M.Pd. beliau merupakan dosen Pendidikan Biologi Fakultas Sains dan Teknologi UIN Suanan

\footnotetext{
${ }^{25}$ Wawancara dengan Ibu Ratna Dyah Astuti, Wali Kelas 4 SLB A Yaketunis Yogyakarta, di Ruang Tamu SLB A Yaketunis Yogyakarta, dan dengan Ibu Sofia Patriati H, Wali Kelas 3, di Ruang Kelas 3 SLB A Yaketunis Yogyakarta, tanggal 21 November 2018.

26 Wawancara dengan Ibu Sri Wahyuni Endaryati, guru matematika SLB A Yaketunis Yogyakarta, di ruang tamu SLB A Yaketunis Yogyakarta, tanggal 16 Januari 2018.

${ }^{27}$ Mulyatiningsih, Metode Penelitian Terapan Bidang Pendidikan..., hlm. 198.
} 
Kalijaga Yogyakarta, beliau ahli dalam evaluasi sehingga layak menjadi ahli evaluasi dalam penelitian ini. Selanjutnya ahli Instrumen yaitu Dra. Suparni, M.Pd, beliau merupakan dosen Pendidikan Matematika Fakutas Sains dan Teknologi UIN Sunan Kalijaga Yogyakarta. Beliau ahli dalam hal instrumen sehingga layak menjadi ahli evaluasi dalam penelitian ini. Yang terakhir ahli materi yaitu Dr. Ibrahim, M. Pd beliau merupakan dosen Pendidikan Matematika Fakultas Sains dan Teknologi UIN Sunan Kalijaga Yogyakarta. Beliau merupakan ahli dalam bidang disposisi matematis sehingga beliau layak menjadi ahli materi dalam penelitian ini.

Selain divalidasi oleh para ahli, penelitian ini juga ditinjau oleh guru SDLB A Yaketunis Yogyakarta yaitu Sri Wahyuni Endaryati, S.Pd selaku guru matematika SDLB A Yaketunis Yogayakarta, sehingga beliau layak menjadi peninjau dalam penelitian ini. Beliau juga lebih mengerti langsung keadaan di SDLB A Yaketunis Yogayakarta. Selanjutnya peneliti juga meminta beberapa teman sejawat seperti: Achmad Mukhlasin merupakan mahasisiwa PGMI Fakultas Ilmu Tarbiyah dan Keguruan UIN Sunan Kalijaga Yogyakarta, Sofyan Alfin merupakan mahasisiwa PGMI Fakultas Ilmu Tarbiyah dan Keguruan UIN Sunan Kalijaga Yogyakarta, Siwi Aminah Pangestu merupakan mahasisiwi PGMI Fakultas Ilmu Tarbiyah dan Keguruan UIN Sunan Kalijaga Yogyakarta, Ridho Hardiansyah merupakan mahasisiwa BKI Fakultas Dakwah dan Komunikasi UIN Sunan Kalijaga Yogyakarta.

Kedua Developmental testing, merupakan kegiatan uji coba rancangan produk pada sasaran subjek yang sesungguhnya. Pada 
saat uji coba ini dicari data respon peserta didik yaitu Anas Rohman Saputra, Khoirun Nisa Fauzih dan Rina Utami. Setelah produk diperbaiki kemudian diujikan kembali sampai memperoleh hasil yang efektif.

Dissemination dilakukan dengan menerbitkan hasil penelitian ini di repository perpustakaan pusat UIN Sunan Kalijaga Yogyakarta. Di samping itu, laporan dan hasil penelitian ini juga disimpan di perpustakaan SDLB A Yaketunis Yogyakarta. Dengan demikian, hasil penelitian ini dapat memiliki nilai guna dan kebermanfaatan baik dalam konteks empiris di lapangan maupun sebagai bahan kajian akademik untuk penelitian berikutnya.

\section{HASIL PENELITIAN DAN PEMBAHASAN}

Pada bagian ini, peneliti menguraikan dua pokok bahasan yaitu proses pengembangan instrumen penilaian sikap disposisi matematis dan hasil uji kelayakan instrumen. Penjelasan selengkapnya diuraikan berikut ini.

\section{Proses Pengembangan Instrumen Penilaian Sikap Disposisi Matematis}

Instrumen penilaian sikap disposisi matematis untuk siswa tunanetra di jenjang Sekolah Dasar Luar Biasa untuk materi Faktor Persekutuan Terbesar (FPB) dan Kelipatan Persekutuan Terkecil (KPK) ini dikembangkan dengan 4 tahapan sebagai berikut: pertama, yaitu tahap define. Define ini memiliki 2 hal yaitu; satu identifikasi masalah, pada tahap ini peneliti melakukan observasi terhadap peserta didik SDLB A Yaketunis Yogyakarta, dari observasi tersebut dapat 
disimpulkan bahwa belum tersedianya instrumen penilaian sikap yang digunakan dalam penilaian proses evaluasi dan hanya berupa soal-soal kognitif saja $^{28}$ dan masih kurangnya kemampuan berhitung peserta didik kelas $4 .^{29}$ Selain itu, dalam proses pembuatan instrumen penilaian tidak sempat untuk diuji secara mendetail, hanya pada even tertentu saja seperti ujian nasional. ${ }^{30}$ Padahal, semua penilaian pada semua ranah harus dilengkapi dengan instrumen. ${ }^{31}$

Kedua analisis latar, pada tahap ini peneliti melakukan beberapa kunjungan ke SDLB yang ada di Yogyakarta yaitu: SDLB A Yaketunis Yogyakarta yaitu pada tanggal 16 Januari 2018, SDLB N 1 Bantul yaitu tanggal 01 Februari 2018 dan SDLB N 1 Kulon Progo yaitu tanggal 02 Februari 2018. Pada SDLB N 1 Kulon Progo peneliti menemukan bahwa penilaian sikap disposisi matematis di sana belum ada, ${ }^{32}$ namun karena jarak yang jauh SDLB N 1 Kulon Progo tidak menjadi tempat penelitian. Sedangkan pada SDLB N 1 Bantul peneliti menemukan bahwa di sana sudah menggunakan penilaian sikap dengan mengacu pada penilaian sikap yang ada pada buku

\footnotetext{
${ }^{28}$ Wawancara dengan Refli, siswa kelas 4 SLB A Yaketunis Yogyakarta. Di depan ruang kelas 4, tanggal 16 Januari 2018.

${ }^{29}$ Wawancara dengan Ibu Ratna Dyah Astuti, Wali Kelas 4 SLB A Yaketunis Yogyakarta, di Ruang Tamu SLB A Yaketunis Yogyakarta, dan dengan Ibu Sofia Patriati H, Wali Kelas 3, di Ruang Kelas 3 SLB A Yaketunis Yogyakarta, tanggal 21 November 2018.

30 Wawancara dengan Ibu Sri Wahyuni Endaryati, guru matematika SLB A Yaketunis Yogyakarta, di ruang tamu SLB A Yaketunis Yogyakarta, tanggal 16 Januari 2018.

${ }^{31}$ Arikunto, Dasar-Dasar Evaluasi Pendidikan..., hlm. 26.

32 Wawancara dengan Bapak Abdul Abidin, guru kelas 4 SLB N 1 Bantul Yogyakarta, di ruang media SLB N1 Bantul Yogyakarta, tanggal 01 Februari 2018 di SDLB N 1 Bantul Yogyakarta
} 
Tematik Terapan tapi belum menggunakan penilaian diri. ${ }^{33}$ Peneliti tidak melakukan penelitian di SDLB N 1 Bantul dikarenakan jarak masih cukup jauh.

Peneliti menemukan bahwa penilaian proses di SDLB A Yaketunis Yogyakarta hanya berupa soal-soal kognitif saja ${ }^{34}$ dan masih kurangnya kemampuan berhitung peserta didik kelas $4 .^{35}$ Sehingga peneliti memilih SDLB A Yaketunis sebagai tempat di mana penelitian ini dilaksanakan. Selain itu, peneliti memilih SDLB A Yaketunis Yogyakarta tersebut disebabkan letak geografisnya yang relatif paling dekat sehingga dapat memperkecil biaya pengembangan.

Tahap kedua, yaitu design. Design dilakukan dengan beberapa langkah sebagai berikut: pertama masalah yang diangkat dalam penelitian ini adalah belum tersedianya instrumen penilaian sikap yang digunakan dalam penilaian proses evaluasi dan hanya berupa soal-soal kognitif saja ${ }^{36}$ serta masih kurangnya kemampuan berhitung peserta didik kelas 4. ${ }^{37}$ Selain itu, dalam proses pembuatan instrumen penilaian tidak

\footnotetext{
${ }^{33}$ Wawancara dengan Bapak Amiruddin Al Qodri, guru kelas 4 dan 5 SLB N 1 Kulon Progo, di ruang kelas 4 dan 5 SLB N 1 Kulon Progo Yogyakarta, tangal 02 Februari 2018.

34 Wawancara dengan Refli, siswa kelas 4 SLB A Yaketunis Yogyakarta. Di depan ruang kelas 4, tanggal 16 Januari 2018.

35 Wawancara dengan Ibu Ratna Dyah Astuti, Wali Kelas 4 SLB A Yaketunis Yogyakarta, di Ruang Tamu SLB A Yaketunis Yogyakarta, dan dengan Ibu Sofia Patriati H, Wali Kelas 3, di Ruang Kelas 3 SLB A Yaketunis Yogyakarta, tanggal 21 November 2018.

36 Wawancara dengan Refli, siswa kelas 4 SLB A Yaketunis Yogyakarta. Di depan ruang kelas 4, tanggal 16 Januari 2018.

37 Wawancara dengan Ibu Ratna Dyah Astuti, Wali Kelas 4 SLB A Yaketunis Yogyakarta, di Ruang Tamu SLB A Yaketunis Yogyakarta, dan dengan Ibu Sofia Patriati H, Wali Kelas 3, di Ruang Kelas 3 SLB A Yaketunis Yogyakarta, tanggal 21 November 2018.
} 
sempat untuk diuji secara detail, hanya pada even tertentu saja seperti ujian nasional. ${ }^{38}$

Setelah itu ditetapkanlah tujuan penelitian pengembangan ini yaitu tersedianya produk instrumen penilaian sikap disposisi matematis materi FPB dan KPK sebagai alat untuk mengukur sikap disposisi matematis materi FPB dan KPK. Setelah peneliti menentukan tujuan penelitian pengembangan ini, langkah selanjutnya adalah pengembangan ide. Pengembangan ide ini dilakukan atas dasar masukan dari dosen pembimbing, sehingga dipilihlah pengembangan instrumen ini pada mata pelajaran matematika disebabkan masih lemahnya tingkat pemahaman matematika di Indonesia ${ }^{39}$ serta masih kurangnya kemampuan berhitung peserta didik kelas 4 pada SDLB A Yaketunis Yogyakarta, ${ }^{40}$ selain itu dalam proses pembuatan instrumen penilaian tidak sempat untuk diuji secara detail, hanya pada even tertentu saja seperti ujian nasional. ${ }^{41}$ Setelah menentukan mata pelajaran apa yang akan diteliti selanjutnya peneliti atas masukan dari dosen pembimbing menentukan instrumen sikap disposisi matematis sebagai fokus pengembangannya. Hal ini dipilih karena masih rendahnya

38 Wawancara dengan Ibu Sri Wahyuni Endaryati, guru matematika SLB A Yaketunis Yogyakarta, di ruang tamu SLB A Yaketunis Yogyakarta, tanggal 16 Januari 2018.

${ }^{39}$ Gurria, PISA Result in Focus.

${ }^{40}$ Wawancara dengan Ibu Ratna Dyah Astuti, Wali Kelas 4 SLB A Yaketunis Yogyakarta, di Ruang Tamu SLB A Yaketunis Yogyakarta, dan dengan Ibu Sofia Patriati H, Wali Kelas 3, di Ruang Kelas 3 SLB A Yaketunis Yogyakarta, tanggal 21 November 2018.

41 Wawancara dengan Ibu Sri Wahyuni Endaryati, guru matematika SLB A Yaketunis Yogyakarta, di ruang tamu SLB A Yaketunis Yogyakarta, tanggal 16 Januari 2018. 
tingkat pemahaman sikap ${ }^{42}$ dan tingkat pemahaman matematika di Indonesia, ${ }^{43}$ kemampuan berhitung peserta didik kelas 4 SDLB A Yaketunis Yogyakarta. ${ }^{44}$ Karena tanpa adanya disposisi matematis yang baik, maka kemampuan matematika peserta didik akan kurang. ${ }^{45}$ Tahap selanjutnya adalah menentukan materi yang akan diteliti yaitu materi FPB dan KPK, materi ini dipilih karena pada kelas 4 sudah mulai diajarkan. Tahap ini dilaksanakan pada tanggal 09 Maret 2018 pada revisi ketiga dan produk baru berupa rancangan dalam proposal.

Langkah selanjutnya adalah penyaringan ide. Dalam tahap ini peneliti melakukan penyaringan atas masukan dari dosen pembimbing. Penyaringan ini adalah proses pemilihan metode penilaian sikap yaitu antara penilaian diri, antara teman, observasi ataukah jurnal. Dipilihlah penilaian diri sebagai metode penilaian yang digunakan dalam produk yang peneliti kembangkan. Begitu juga dalam pengembangan ini dipilihlah sistem pengumpul data berupa angket dengan skala likert sebagai metode pengumpul datanya. Tahap ini dilakukan pada tanggal 18 Mei 2018 pada revisi kedelapan, pada tahap ini masih berupa proposal.

\footnotetext{
${ }^{42}$ Hardoko, Indeks Persepsi 2017: Peringkat Indonesia Di Bawah Timor Leste.

${ }^{43}$ Gurria, PISA Result in Focus.

${ }^{44}$ Wawancara dengan Ibu Ratna Dyah Astuti, Wali Kelas 4 SLB A Yaketunis Yogyakarta, di Ruang Tamu SLB A Yaketunis Yogyakarta, dan dengan Ibu Sofia Patriati H, Wali Kelas 3, di Ruang Kelas 3 SLB A Yaketunis Yogyakarta, tanggal 21 November 2018.

45 Feldaus, "How Mathematical Disposition and Intellectual Development Influence Teacher Candidates' Mathematical Knowledge for Teaching in a Mathematics Course for Elementary School Teachers."
} 
Pasca penyaringan ide dilaksanakan, langkah selanjutnya adalah pengevaluasian yakni pada tanggal 03 Agustus 2018. Pada tahap ini, peneliti membuat pedoman pengembangan instrumen yang akan digunakan sebagai sebuah produk instrumen penilaian sikap disposisi matematis melalui masukan dari dosen pembimbing. Berikutnya adalah pertimbangan konsumen. Pada tahap ini, peneliti meminta pendapat dari guru matematika SDLB A Yaketunis bahwa pengembangan instrumen penilaian sikap disposisi matematis ini perlu atau layak dikembangkan. ${ }^{46}$ Adapun masukan dari beliau belum ada, disebabkan produk masih berupa rancangan dalam proposal. Langkah terakhir adalah desain produk. Pada tahap ini peneliti membuat desain produk awal seperti pada gambar 1 .

46 Wawancara dengan Ibu Sri Wahyuni Endaryati, guru matematika SLB A Yaketunis Yogyakarta, di ruang tamu SLB A Yaketunis Yogyakarta, tanggal 16 Januari 2018. 


\section{LEMBAR PENILAIAN DIRI}

\section{SIKAP DISPOSISI MATEMATIS}

Petunjuk

1. Tulislah identitasmu sebelum mengisi angket

2. Bacalah pernyataan yang ada di dalam kolom dengan benar

3. Berilah tanda centang sesuai dengan keadaan yang sebenamya.

Identitas Responden

Nama

Kelas

Materi : Matematika

Tanggal

\begin{tabular}{|l|l|l|l|l|l|}
\hline No & Pernyataan & STS & TS & S & SS \\
\hline 1. & $\begin{array}{l}\text { Saya berani bertanya ketika saya tidak paham } \\
\text { dalam pembelajaran FPB dan KPK(+) }\end{array}$ & & & & \\
\hline 2. & $\begin{array}{l}\text { saya dapat mengerjakan soal FPB dan KPK } \\
\text { dengan baik (+). }\end{array}$ & & & & \\
\hline 3. & $\begin{array}{l}\text { saya takut bertanya kepada ibu guru saat } \\
\text { pembeajaran materi FPB dan KPK sedang } \\
\text { berlangsung (-) }\end{array}$ & & & & \\
\hline 4. & $\begin{array}{l}\text { saya kesulita dalam memahami materi FPB dan } \\
\text { KPK(-) }\end{array}$ & & & & \\
\hline 5. & $\begin{array}{l}\text { saya mencoba berbagai cara dalam mengerjakan } \\
\text { soal materi FPB dan KPK(+). }\end{array}$ & & & \\
\hline
\end{tabular}

Gambar 1

Produk Awal

Tahap ketiga, yaitu develop. Pada tahap ini peneliti melakukan kegiatan expert apprasial (validasi penilaian) baru kemudian melakukan Developmental testing secara bertahap. Validasi pertama adalah validasi oleh ahli instrumen yakni Dr. Suparni, M.Pd, validasi kedua oleh ahli evaluasi yaitu Runtut Prih Utami, M.Pd dan validasi ketiga oleh ahli materi yaitu Dr. Ibrahim, M.Pd. Selain para ahli di atas, peneliti juga meminta masukan dari guru SDLB A Yaketunis yaitu Sri Wahyuni Endaryati, S.Pd serta teman sejawat yaitu Achmad Mukhlasin, Sofyan Alfin, Siwi Aminah Pangestu dan Ridho Hardiansyah. Dari penilaian oleh para ahli, guru, dan teman sejawat di atas, 
dapat disimpulkan bahwa produk yang dikembangkan sudah layak digunakan dengan revisi. Produk sesudah divalidasi oleh para ahli, guru dan teman sejawat setelah direvisi dapat dilihat pada gambar 2 .

\section{LEMBAR PENILAIAN DIRI}

\section{SIKAP DISPOSISI MATEMATIS}

\section{Petunjuk}

1. Tulislah identitasmu sebelum mengisi angket

2. Bacalah pernyataan yang ada di dalam kolom dengan benar

3. Tulislah kode kriteria dilembar kerja yang telah disediakan. Mengacu pada skala penilaian berikut

\begin{tabular}{|l|l|l|}
\hline Kriteria & Kode & Kriteria penilaian \\
\hline Sangat setuju & SS & 4 kriteria terpenuhi \\
\hline Setuju & S & 3 kriteria terpenuhi \\
\hline Tidak setuju & TS & 2 kriteria terpenuhi \\
\hline Sangat tidak setuju & STS & 1 kriteria terpenuhi \\
\hline
\end{tabular}

Identitas Responden

Nama

Kelas

Materi $\quad$ : FPB dan KPK/ Matematika

Tanggal

1. Saya berani bertanya ketika saya tidak paham dalam pembelajaran FPB dan KPK.

Kreiteria Penilaian : Bertanya

Keterangan

Pertanyaan yang dilakukan secara jelas dan singkat

> Pertanyaan yang dilakukan bertujuan menjelasakan

$>$ Pertanyaan yang dilakukan mengenai penerapan suatu hal

$>$ Pertanyaan tetap dilakukan walaupun mungkin peserta didik lain tidak membutuhkan pertanvaan tersebut.

\section{Gambar 2}

\section{Produk Final}

Tahap keempat, yaitu disseminate. Tahap ini merupakan tahap menyebarluaskan produk hasil 
pengembangan. Produk yang telah dikembangkan oleh peneliti dijadikan koleksi perpustakaan SDLB A Yaketunis Yogyakarta. Di samping itu, laporan penelitian ini sekaligus produk dari penelitian ini menjadi koleksi digital di repository perpustakaan UIN Sunan Kalijaga Yogyakarta.

\section{Kelayakan Instrumen Penilaian Disposisi Matematis pada Materi FPB dan KPK untuk Siswa Tunanetra pada Sekolah Dasar Luar Biasa}

a. Validasi

Uji validasi meliputi tiga aspek, yaitu validasi isi, validasi konstruk, dan validasi kriteria. Validasi isi, validasi ini terdiri dari validasi isi yang divalidasi oleh Dr. Suparni, M.Pd sebagai validator ahli instrumen. Selanjutnya validasi isi yang divalidasi oleh Runtut Prih Utami, M.Pd, beliau sebagai validator ahli evaluasi. Yang terakhir adalah validasi isi yang divalidasi oleh Dr. Ibrahim, M.Pd, beliau sebagai ahli materi. Dan semuanya sudah sudah menyatakan valid.

Validasi konstruk, validasi ini memiliki dua bagian yaitu, pertama validasi prediktif, validasi ini mengacu pada hasil tiga penilaian yang dilakukan kepada tiga peserta didik yang berbeda yaitu, Khoirun Nisa Fauziah, Anas Rohman Saputra dan Rina Utami peserta didik SDLB A Yaketunis. Percobaan pertama dilaksanakan kepada dua peserta didik yaitu Anas Rohman Saputra dan Rina Utami dihasilkan jumlah total adalah 61 dan 65. Pada percobaan kedua 
dihasilkan sebesar 63 dan 65. Jika dilihat dari hasil ini dapat dilihat bahwa ada peningkatan pada saudara Anas Rohman Saputra. Selanjutnya dilihat dari data uji coba kedua kepada Rina Utami yang menujukkan jumlah total skor sebesar 65 dan Khoirun Nisa Fauziah yang menujukkan jumlah total skor sebesar 57 serta pada uji coba ketiga yang menunjukkan jumlah total skor Rina Utami sebesar 75 dan Khoirun Nisa Fauziah sebesar 60. Jika dilihat dari hasl ini dapat diprediksi bahwa percobaan selanjutnya akan lebih besar nilainya.

Kedua validasi konkuren, validasi ini mengacu pada hasil penilaian diri pertama, kedua dan ketiga yang diikuti oleh tiga peserta didik yaitu saudara Anas Rohman Saputra, saudari Rina Utami dan Khoirun Nisa Fauziah. Pada percobaan pertama yang diikuti oleh saudara Anas Rohman Saputa dan Khoirun Nisa Fauziah yang masing-masing mendapatkan skor total sebesar 61 dan 65. Pada percobaan kedua dihasilkan skor total sebesar 63 dan 65. Hasil ini menunjukkan sikap disposisi matematis kedua peserta didik tersebut sama. Kemudian pada percobaan kedua dan ketiga yang diikuti oleh saudari Rina Utami dengan Khorun Nisa Fauzaih yang menunjukkan skor total sebesar 65, 75 dan 53, 57. Hasil ini menunjukkan bahwa Rina Utami memiliki sikap disposisi matematis yang lebih baik dari pada Khoirun Nisa Fauziah.

Validasi ketiga yaitu validasi kriteria. Validasi ini mengacu pada kesesuaian penilaian dari penilaian antar 
teman dengan penilaian pribadi yang dapat dilihat pada tabel hasil uji coba ketiga, yang menunjukkan bahwa pada penilaian diri yaitu menghasilkan nilai sebesar 75 untuk saudari Rina Utami dan 60 untuk saudari Khoirun Nisa Fauziah. Sedangkan pada penilaian antar teman saudari Rina Utami mendapatkan nilai sebesar 31 sedangkan saudari Khoirun Nisa Fauziah sebesar 24. Hasil ini menunjukkan korelasi yang baik antara penilaian antar teman dengan penilaian diri, yaitu sama-sama menunjukkan bahwa saudari Rina Utami memiliki sikap disposisi matematis yang lebih baik dari pada Khoirun Nisa.

b. Reliabilitas

Uji reliabilitas dalam penelitian ini dilakukan melalui uji coba terbatas, uji coba pertama, uji coba kedua, hingga uji coba ketiga. Penjelasan masing-masing uji tersebut diuraikan berikut ini. Pertama, uji coba terbatas. Reliabilitas pada pra-ujicoba yang dilaksanakan pada tanggal 05 Oktober 2018 di SDLB A Yaketunis Yogyakarta yang diikuti oleh 3 peserta didik yaitu: Rina yang memiliki total skor sebanyak 32, Nisa menghasilkan total skor sebanyak 26 dan Anas memiliki total skor sebanyak 29, telah mengisi 10 item angket yang telah disediakan. Setelah dianalisis menggunakan SPSS 24 didapatkan reliabilitas sebesar 0,611. Hasil uji coba terbatas dapat dilihat pada Tabel 1. 
Tabel 1

Reliabilitas Uji Coba Terbatas

\begin{tabular}{|c|c|}
\hline \multicolumn{2}{|c|}{ Reliability Statistics } \\
\hline Cronbach's & \\
\hline Alpha & $\mathrm{N}$ of Items \\
\hline, 611 & 11 \\
\hline
\end{tabular}

Dengan demikian, produk Instrumen yang dikembangkan belum layak dikarenakan tidak memenuhi reliabilitas minimum yaitu $0,7 .{ }^{47}$ Butir soal tersebut kemudian direvisi dengan mengubah beberapa tata letak produk berdasarkan saran pada tanggal 05 Oktober 2018 dari peserta didik. Setelah produk selesai direvisi maka produk diujicobakan kepada peserta didik. Uji coba ini sebagi uji coba yang pertama.

Uji coba pertama ini dilaksanakan pada tanggal 11 Oktober 2018 di SDLB A Yaketunis yang diikuti oleh dua orang yaitu Anas dan Rina, yang mengisi seluruh angket yang berjumlah 22 item yang memiliki total skor masingmasing sebesar 61 dan 65. Setelah diuji dengan SPSS 24 didapatkan reliabilitas sebesar 0,555 (lihat tabel 2). Disebabkan belum memenuhi nilai 0,7 maka instrumen belum reliabel ${ }^{48}$ sehingga produk yang dikembangkan belum layak digunakan.

47 Saifudin Azwar, Validitas Dan Reliabilitas, 9th ed. (Yogyakarta: Pustaka Pelajar, 2018), hlm. 98.

${ }^{48}$ Azwar. 
Tabel 2

Reliabilitas Uji Coba Pertama

\begin{tabular}{rr}
\hline \multicolumn{2}{c}{ Reliability Statistics } \\
\hline $\begin{array}{lr}\text { Cronbach's } \\
\text { Alpha }\end{array}$ & N of Items \\
\hline, 555 & 23 \\
\hline
\end{tabular}

Produk ini kemudian diperbaiki dengan masukan dari guru matematika SDLB A Yaketunis yaitu Sri Wahyuni Endaryati, S.Pd pada tanggal 11 Oktober 2018, dan tinjauan teman sejawat yaitu Achmad Mukhlasin, Siwi Aminah Pangestu, Sofyan Alfin pada tanggal 17 Oktober 2018 serta masukan dari Ahli Evaluasi pada tanggal 26 Oktober 2018.

Setelah revisi selesai pada tanggal 29 Oktober 2018 produk diuji coba lagi di SDLB A Yaketunis sebagi uji coba kedua yang diikuti oleh tiga orang yaitu Rina, Anas dan Nisa yang seluruhnya mengisi 22 angket yang telah disediakan dan masing-masing memiliki total skor sebesar 65, 63 dan 57. Setelah hasil uji coba diperoleh, hasil tersebut dianalisis menggunakan SPSS 24 sehingga didapatlah reliabilitas sebesar 0,407 lihat tabel di bawah. Hasil ini menunjukkan bahwa instrumen yang digunakan masih di bawah 0,7 dimana 0,7 ini adalah reliabilitas minimal untuk instrumen penilaian. ${ }^{49}$

49 Azwar. 
Tabel 3

Hasil Uji Coba Kedua

\begin{tabular}{rr}
\hline \multicolumn{2}{c}{ Reliability Statistics } \\
Cronbach's Alpha & N of Items \\
\hline, 407 & 23 \\
\hline
\end{tabular}

Total skor untuk tiap-tiap item dapat dilihat pada tabel 4 berikut ini.

Tabel 4

Total Item Statistik

\begin{tabular}{lcccc}
\hline \multicolumn{5}{c}{ Item-Total Statistics } \\
& $\begin{array}{c}\text { Scale Mean } \\
\text { if Item } \\
\text { Deleted }\end{array}$ & $\begin{array}{c}\text { Scale } \\
\text { Variance if } \\
\text { Item Deleted }\end{array}$ & $\begin{array}{c}\text { Corrected } \\
\text { Item-Total } \\
\text { Correlation }\end{array}$ & $\begin{array}{c}\text { Cronbach's } \\
\text { Alpha if Item } \\
\text { Deleted }\end{array}$ \\
\hline item1 & 120,33 & 69,333 &, 000 &, 408 \\
\hline item2 & 120,33 & 69,333 &, 000 &, 408 \\
\hline item3 & 121,33 & 69,333 &, 000 &, 408 \\
\hline item4 & 119,67 & 60,333 &, 966 &, 318 \\
\hline item5 & 120,00 & 52,000 &, 961 &, 222 \\
\hline item6 & 120,67 & 57,333 &, 610 &, 298 \\
\hline item7 & 121,33 & 65,333 &, 000 &, 433 \\
\hline item8 & 119,67 & 60,333 &, 966 &, 318 \\
\hline item9 & 119,33 & 69,333 &, 000 &, 408 \\
\hline item10 & 121,00 & 79,000 &,- 974 &, 491 \\
\hline item11 & 120,00 & 52,000 &, 961 &, 222 \\
\hline item12 & 119,67 & 60,333 &, 966 &, 318 \\
\hline item13 & 121,00 & 91,000 &,- 655 &, 610 \\
\hline item14 & 119,67 & 76,333 &,- 727 &, 471 \\
\hline item15 & 120,00 & 52,000 &, 961 &, 222 \\
\hline item16 & 121,00 & 79,000 &,- 974 &, 491 \\
\hline item17 & 120,67 & 50,333 &, 769 &, 215 \\
\hline item18 & 121,33 & 64,333 &, 072 &, 407 \\
\hline item19 & 121,33 & 82,333 &,- 771 &, 522 \\
\hline item20 & 122,00 & 63,000 &, 655 &, 349 \\
\hline item21 & 119,67 & 72,333 &,- 339 &, 439 \\
\hline & & & & \\
\hline
\end{tabular}




\begin{tabular}{lrrrr}
\hline \multicolumn{4}{c}{ Item-Total Statistics } \\
\hline & $\begin{array}{c}\text { Scale Mean } \\
\text { if Item } \\
\text { Deleted }\end{array}$ & $\begin{array}{c}\text { Scale } \\
\text { Variance if } \\
\text { Item Deleted }\end{array}$ & $\begin{array}{c}\text { Corrected } \\
\text { Item-Total } \\
\text { Correlation }\end{array}$ & $\begin{array}{c}\text { Cronbach's } \\
\text { Alpha if Item } \\
\text { Deleted }\end{array}$ \\
\hline item22 & 121,67 & 86,333 &,- 681 &, 562 \\
\hline Total & 61,67 & 17,333 & 1,000 &,$- 463^{\mathrm{a}}$ \\
\hline
\end{tabular}

a. The value is negative due to a negative average covariance among items. This violates reliability model assumptions. You may want to check item codings.

Dengan demikian, produk ini masih perlu diperbaiki lagi mengacu pada masukan dari ahli materi tanggal 31 Oktober 2018 oleh Dr. Ibrahim, M.Pd dan tinjauan teman sejawat yaitu Ridho Hardiansyah pada tanggal 27 Oktober 2018.

Setelah revisi yang mengacu masukan dari ahli materi dan teman sejawat kemudian produk diujicobakan lagi sebagai uji coba ketiga. Uji coba ini diikuti oleh 2 orang peserta didik yaitu Rina dan Nisa yang seluruhnya mengisi 22 angket yang telah disediakan masing-masing memiliki total skor sebesar 75 dan 60. Berdasarkan perhitungan menggunakan SPSS 24, reliabilitas yang dihasilkan sebesar 0,73, hal ini menunjukkan bahwa instrumen yang disediakan sudah reliabel karena sudah memenuhi kriteria minimal yaitu $<0,7 .{ }^{50}$ Dengan demikian, produk ini telah layak untuk digunakan.

${ }^{50}$ Azwar. 
Tabel 5

Reliabilitas Uji Coba Ketiga

Reliability Statistics

Cronbach's

Alpha $\quad \mathrm{N}$ of Items

, $729 \quad 23$

Total itemnya dapat dilihat pada Tabel 6 berikut ini.

Tabel 6

Total Item Statistik

\section{Item-Total Statistics}

\begin{tabular}{lrrrr}
\hline & $\begin{array}{c}\text { Scale Mean if } \\
\text { Item Deleted }\end{array}$ & $\begin{array}{c}\text { Scale } \\
\text { Variance if } \\
\text { Item Deleted }\end{array}$ & $\begin{array}{c}\text { Corrected } \\
\text { Item-Total } \\
\text { Correlation }\end{array}$ & $\begin{array}{c}\text { Cronbach's } \\
\text { Alpha if Item } \\
\text { Deleted }\end{array}$ \\
\hline item1 & 131,50 & 420,500 & 1,000 &, 710 \\
\hline item2 & 131,50 & 480,500 & $-1,000$ &, 752 \\
\hline item3 & 132,00 & 392,000 & 1,000 &, 690 \\
\hline item4 & 131,50 & 420,500 & 1,000 &, 710 \\
\hline item5 & 132,50 & 480,500 & $-1,000$ &, 752 \\
\hline item6 & 132,00 & 450,000 &, 000 &, 731 \\
\hline item7 & 132,00 & 392,000 & 1,000 &, 690 \\
\hline item8 & 132,00 & 392,000 & 1,000 &, 690 \\
\hline item9 & 133,00 & 512,000 & $-1,000$ &, 773 \\
\hline item10 & 131,50 & 480,500 & $-1,000$ &, 752 \\
\hline item11 & 132,00 & 392,000 & 1,000 &, 690 \\
\hline item12 & 131,50 & 420,500 & 1,000 &, 710 \\
\hline item13 & 132,00 & 450,000 &, 000 &, 731 \\
\hline item14 & 131,50 & 420,500 & 1,000 &, 710 \\
\hline item15 & 132,50 & 364,500 & 1,000 &, 670 \\
\hline item16 & 131,50 & 420,500 & 1,000 &, 710 \\
\hline item17 & 132,00 & 450,000 &, 000 &, 731 \\
\hline item18 & 132,00 & 450,000 &, 000 &, 731 \\
\hline item19 & 132,00 & 392,000 & 1,000 &, 690 \\
\hline item20 & 132,50 & 480,500 & $-1,000$ &, 752 \\
\hline item21 & 131,50 & 420,500 & 1,000 &, 710 \\
\hline & & & &
\end{tabular}




\begin{tabular}{lrrrr}
\hline item22 & 132,00 & 392,000 & 1,000 &, 690 \\
\hline Total & 67,50 & 112,500 & 1,000 &, 829 \\
\hline
\end{tabular}

Berdasarkan tabel 6 di atas dapat dilihat bahwa nilai reliabilitas setiap item. Terdapat 7 item yaitu item nomor 3 , 7, 8, 11, 15, 19 dan 22 masih di bawah 0,7 dan mayoritas item yang lain sudah menunjukkan lebih dari 0,7. Dengan demikian, instrumen ini dapat dikatakan reliabel. Sementara itu, 7 item yang tidak reliabel tersebut tidak digunakan lagi.

\section{SIMPULAN}

Penelitian pengembangan instrumen penilaian sikap disposisi matematis untuk materi FPB dan KPK bagi siswa tunanetra pada jenjang Sekolah Dasar Luar Biasa telah berhasil dikembangkan dengan metode 4D yaitu: (1) Define (pendefinisian), di sini peneliti melakukan analisis kebutuhan dengan melakukan wawancara dengan 3 orang guru dari 3 sekolah yakni SDLB A Yaketunis Yogyakarta, SDLB N 1 Bantul dan SDLB N 1 Kulon Progo serta melakukan wawancara dengan peserta didik; (2) Design (Perancangan) peneliti merancang produk dengan analisis yang ada; (3) Developed (pengembangan) peneliti melakukan pengembangan yang kemudian divalidasi oleh ahli materi, ahli instrumen dan ahli evaluasi, serta melakukan tiga kali uji coba terhadap 3 peserta didik; (4) Desseminate, yaitu peneliti menyebarluaskan produk dengan menjadikannya sebagai koleksi perpustakaan di SDLB A Yaketunis Yogyakarta dan repository perpustakaan UIN Sunan Kalijaga Yogyakarta. 
Di samping itu, berdasarkan penilaian yang dilakukan oleh tiga validator diperoleh hasil yaitu instrumen penilaian sikap disposisi matematis sudah valid serta berdasarkan analisis menggunakan Combach Alpha didapatkan bahwa reliabilitas instrumen sudah memenuhi skor lebih dari 0,70, sehingga memiliki reliabilitas tergolong sedang. Dengan demikian, produk ini memiliki tingkat error sebesar 30\%. Hal ini artinya, produk instrumen penilaian sikap disposisi matematis materi FPB dan KPK layak digunakan sebagai instrumen penilaian di MI/SD.

\section{E. DAFAR PUSTAKA}

Admin Sosbud. Rangking Pendidikan Negara-Negara Asean, 2018. http://www.dw.com/id/rangking-pendidikan-negara-negaraasean/g-37594464.

Arikunto, Suharsimi. Dasar-Dasar Evaluasi Pendidikan. Revisi. Jakarta: Bumi Aksara, 2010.

Azwar, Saifudin. Validitas Dan Reliabilitas. 9th ed. Yogyakarta: Pustaka Pelajar, 2018.

Feldaus, C. Adam. "How Mathematical Disposition and Intellectual Development Influence Teacher Candidates' Mathematical Knowledge for Teaching in a Mathematics Course for Elementary School Teachers." Disertasi, Ohio: The Patton College of Education, 2012. https://etd.ohiolink.edu/!etd.send_file?accession=ohiou1343 753975\&disposition=inline.

Gurria, Angel. PISA Result in Focus, 2018. https://www.oecd.org/pisa/pisa-2015-results-in-focus.pdf.

Hardoko, Ervan. Indeks Persepsi 2017: Peringkat Indonesia Di Bawah Timor Leste, 2017. https://internasional.kompas.com/read/2018/02/26/1444450 1/indeks-persepsi-korupsi-2017-peringkat-indonesia-dibawah-timor-leste.

I Ketut Patra, Junaidi. "Korupsi, Pertumbuhan Ekonomi Dan Kemiskinan Di Indonesia." Riset Akuntansi Dan Keuangan 
Indonesia $3, \quad$ no. 1 (2018): $71-79$. https://doi.org/10.23917/reaksi.v3i1.5609.

Maghfuroh, Maula Amalia. "Pengaruh Kecerdasan Emosional Dan Disposisi Matematis Peserta Didik Terhadap Hasil Belajar Kognitif Matematika Di Kelas XI MA NU 10 Sukorejo." Skripsi, Universitas Islam Negeri Walisongo Semarang, 2016.

http://eprints.walisongo.ac.id/5898/8/LAMPIRAN.pdf.

Mulyatiningsih, Endang. Metode Penelitian Terapan Bidang Pendidikan. 1st ed. Bandung: Alfabeta, 2012.

Nurkancana, Wayan, and Sunartana. Evaluasi Pendidikan. Surabaya: Usaha Nasional, 1986.

Presiden Republik Indonesia. Undang-Undang Dasar Negara Republik Indonesia Pasal 31 Tahun 1945, n.d.

—. Undang-Undang No 20 Tahun 2003 Tentang Sistem Pendidikan Nasional, n.d.

Sudaryono. Dasar-Dasar Evaluasi Pembelajaran. Yogyakarta: Graha Ilmu, 2012.

Sugiyono. Metode Penelitian Dan Pengembangan. Bandung: Alfabeta, 2017.

Wawancara dengan Bapak Abdul Abidin. guru kelas 4 SLB N 1 Bantul Yogyakarta. di ruang media SLB N1 Bantul Yogyakarta. tanggal 01 Februari 2018.

Wawancara dengan Bapak Amiruddin Al Qodri. guru kelas 4 dan 5 SLB N 1 Kulon Progo. di ruang kelas 4 dan 5 SLB N 1 Kulon Progo Yogyakarta. tanggal 02 Februari 2018.

Wawancara dengan Ibu Sri Wahyuni Endaryanti. guru matematika SLB A Yaketunis Yogyakarta. di ruang tamu SLB A Yaketunis Yogyakarta. tanggal 16 Januari 2018. 
